Lamond's splendid steam yacht Diana, and will proceed vid Nova Zembla, sailing from Dundee on June 1. Capt. Brown, Peterhead, will command the Dianz.

ON the 20 th inst. a large representative meeting of various corporate towns was held at the Society of Arts, Adelphi, under the presidency of Lord Hampton, in relerence to the national museums. The following resolutions were passed unanimously:-I. "That all museums and galleries supported or subsidised by Parliament should be made conducive to the advancement of education and technical instruction to the fullest possible extent, and that special Parliamentary funds should be granted to assist local and provincial museums in the acquisition and loan of objects, and with building grants, and thus extend their usefulness." 2 . "That in the opinion of this meeting all national museums and galleries should be placed under the authority of a Minister of the Crown, with direct responsibility to Parliament, thereby rendering unnecessary for the purposes of executive administration unpaid and irresponsible trustees except those who are trustees under bequests or deeds, who might continue to have the full powers of their trust, but should not be charged with the expenditure of money voted by Parliament." The chairman was requested to submit to the Prime Minister the foregoing resolu. tions, and press their importance on his attention.

WE cannot regret that Lord Hampton's motion for the appointment of a Minister of Education in the House of Lords last Friday was lost. Lord Hampton does not seem to understand what is really required, and the Duke of Richmond's reply under the circumstances was perfectly appropriate and conclusive.

IT is known that several years ago the German Astronomical Socicty undertook the systematic revision of star catalogues for the boreal hemisphere up to the gth magnitude. That heavy task has been undertaken by fourteen observatories-Cambridge (England), Christiania (Norway), Palermo (Italy), Neufchâtel (Switzerland), Leyden (Netherlands), Harvard College and Chicago (U.S.), Pulkowa, Dorpat, Fielsingfors, Kazan (Russia), Berlin, Leipsig, Bonn (Germany). The boreal hemisphere has been divided into zores, ench of which has been allotted to two different observatoiss. Pulkowa was entrusted with the care of observing fundamental stars numbering 539 . The work is just half done, and will be finished by the end of 1875, when every star marked by Lalande in his "Histoire celeste," and Argelander in his star catalogue, will have been revised.

A crolera conference is to meet in Vienna in the course of the autumn, to discuss the best mothods of preventing the propagation of the disense. Prof. Pettenkofer, who has carefuily watched the progress of cholera in Munich since its outbreak nearly a year ago, will be present, and will no doubt have valuable information to contribute. The number of deaths, which last winter amounted to 55 a-day in Munich (as a maximum), had sunk last month to 2 per diem.

THE German Society of Anthropoingy is industriously collecting material for the Prehistoric map, which it was resolved, at the meeting of April r870, to prepare for publication. Among other points to be indicaled on this map will be the position of the most notable Prehistoric settlements, fortifications, lakedwellings, cave-dwellings, burial mounds, and other places of sepulture. By a judicious use of colours, the various periodsStone, Bronze, and Iron-will be indicated, and altogether the map will be one of great value to the student of archrology and ethnology.

We have already referred to the treatment by the French Go vernment of M. Alglave, Professor in the Law Faculty of Douai, and editor of La Revue scientifique. M. Alglave had been dele- gated temporarily to the faculty of Grenoble, but as he had undertaken to deliver a course of lectures at Lille, and had moreover been designated secretary to the approaching session of the French Association at that town, he petitioned the minister to permit him to remain at Douai ; the reply was absolute dismissal from his post without delay. Such is a specimen of how French ministers use their "little brief authority."

LAST Thursday a handsome new aquarium, well stocked with marine and fresh-water fish, was opened at Manchester. The sea-water is brought by train in barrels from Blackpool, a distance of about 40 miles, and a constant supply is maintained.

Mr. J. W. Douglas, the well-known entomologist, has becoms one of the editors of the Entomologist's Monthly Magazine.

THE frst part of the third issue of Sowerby's "British Wild Flowers" (Van Voorst) is now out; the descriptions with an Introduction and a Key to the Natural Orders, being by C. Pierpoint Johnson, Botanical Lecturer at Guy's Hospital.

THE additions to the Zoological Society's Gardens during the last week include a Wild. Boar (Sus scrofa) from Algeria, presented by Mr. W. F. Tempest; an Ourang-outang (Simia satyrus) from Borneo, deposited ; a Racoon-like Dog (Nyctereules viverrinus) from Amoorland, new to the collection; a Great Bustard (Otis tarda), European; five Red-legged Falcons (Erythropus vespertinus), European, purchased ; three Temminck's Tragopans (Ceriomis temmincki) and three Pcacock Pheasants (Polypleciron chinquis), hatched in the Gardens; and two Hairy Armadillos (Dasypus villosus), born in the Gardens.

\section{THE FLORENCE INTERNATIONAL BOTANICAL CONGRESS}

THE International Botanical Congress commenced its sittings at Florence on May I 5, under th Prof. Parlatore being disabled by illness from filling that post. The vice-presidents elected were Mr. Bentham and Dr. Moore for Great Britain, M. de Candolle for Switzerland, M. Fenzl for Austria, MiM. Planchon, Weddell, and Bailion Sor France, MM. Reichenbach, Hofmeister, Wenaland, and Karl Koch for Germany, and MM. Regel, Bunge, Gelernoff, and Wolkerstein for Russia. At the Congress England was represented by Professors Bentham, Aliman, and Mästers, Drs. Hooker and Ball, Messrs. Smee, Hiern, and Maw; David Moore represented Ireland, and Charles Moore Australia.

On the first day a paper was read by Dr. Planchon on Phylloxera vastatrix and the vine disease; on veretable palieontology by M. Camel; on the development of Cymomorium coccinzemm, by Dr. Planchon; M. Famintzin on the spores of Aethaliztin.

At the second meeting, May 18, Prof. de Candolle, presided, and among the papers read was one by Mr. W. P. Hiern, of Cambridge, on the determinations of the fossils that have been referred to Diospyros or allied genera. At the third meeting, May 20, Dr. Bunge, a Russian botanist, presided, and the papers included one by $\mathrm{De}$ Candolle on Alpine plants. On the 16 th took place the inauguration of the bust of Philip Barker Webb, an English botanist, who left his valuable herbarium to Florence. An oration was made by Dr. Bolt, of Berlin.

The International Horticultural Exhibition, which took place concurrently with the Congres:, was opened by the King on the $15^{\text {th }}$, and the following day $\mathrm{I}, 800$ people were present.

The show was beld in a new iron building in the middle of the town, which is to be used as a market. The Ilatian Nerws, published in Rome May 19, says: "The Floral Exhibition has proved a decided success, in spite of the bad weather which accompanied its inauguration. There has been a large daily at:endance. The show was remarkably complete, and the prizes have been awarded with such justice that no jealousies have been allowed to mar the pleasure of the recipients."

It is proposed that the conference for next year shall be held in London. 